Original Research Paper

\title{
Effect of Cow Manure and Atonic on Spinach (Amaranthus spp.) Production in Dry Land
}

\author{
Uly J Riwu Kaho' ${ }^{1}$, Joritha Naisanu ${ }^{1 *}$, Karolina Satria Ida ${ }^{1}$ \\ ${ }^{1}$ Agriculture, Agrotechnology Study Program, 1945 NTT Teachers Association University, Indonesia
}

\author{
Article History \\ Received : September $9^{\text {th }}, 2020$ \\ Revised : September $29^{\text {th }}, 2020$ \\ Accepted : October $3^{\text {th }}, 2020$ \\ Published : October $15^{\text {th }}, 2020$ \\ *Corresponding Author: \\ Joritha Naisanu, \\ Agriculture, Agrotechnology \\ Study Program, 1945 NTT \\ Teachers Association \\ University, Indonesia; \\ Email: \\ jorithanaisanu@gmail.com
}

\begin{abstract}
East Nusa Tenggara is dominated by dry land which has the potential for the development of horticultural crops. Horticultural plants that are widely cultivated by the community are spinach. However, in reality, spinach production in this province is still fluctuating, this is due to the low knowledge of farmers about providing proper nutrition for plant growth and development. For this reason, this study aims to determine the production of spinach in dry land due to cow manure and atonic application. This research was conducted in the experimental field of the Faculty of Agriculture, University of the Teachers Association 1945. The design used was a factorial randomized block design (RBD), which consisted of 2 factors: factor I: cow manure and factor II: growth stimulant (atonic). The results obtained were: The application of cow manure and atonic manure to spinach on dry land had a very significant effect on plant height(7,55 -F hitung> 4,77-F Tabel), number of leaves (10.85-F hitung > 4,77-F Tabel), fresh weight (13,98-F hitung) > 4,77-F Tabel) and dry weight $(6,44-\mathrm{F}$ hitung) $>$ 4,77 -F Tabel).
\end{abstract}

Keywords: Amaranthus spp; organic fertilizer; Atonic; dry land

\section{Introduction}

Kupang Regency is dominated by dry land, with an area of 523,620 ha or $96.53 \%$ with a dry climate as indicated by an average rainfall of 3 - 4 wet months, the remaining dry months. The land area of Kupang Regency is 542,397 ha with altitudes ranging from $0-1,200 \mathrm{~m}$ asl, the topography is generally hilly with a slope of $40 \%$ of the total area(BPS NTT, 2018). Spinach is a short-lived seasonal plant that can adapt to dry land so that it can be cultivated easily in the yard. Spinach is useful as medicine and contains vitamins A, B, C, calories, protein, fat, carbohydrates, calcium, phosphorus and iron (Suwarni Et.al, 2003). Spinach production data in NTT for 20132015 explains that spinach production in NTT for the last 3 years has decreased. This is due to the low level of farmers' knowledge of spinach cultivation techniques and soil fertility, so fertilization is needed to ensure the availability of spinach production in the market (BPS, 2018).

One of the fertilizers that is easily available and available in almost all regions of NTT is cow manure. This fertilizer has natural properties and does not damage the soil, providing macro elements (nitrogen, phosphorus, potassium, calcium, and sulfur) and micro (iron, zinc, boron, cobalt, and molybdenum) (preliminary survey,
2019). Other than that, Manure serves to increase water retention, soil microbiological activity, value of cation exchange capacity and improve soil structure (Magdalena, 2013).Cow manure in the form of solid manure (feces) mixed with food scraps and urine (urine) containing macro and micro elements such as nitrogen $(\mathrm{N})$, phosphate $(\mathrm{P})$, potassium $(\mathrm{K})$, calcium $(\mathrm{Ca})$, magnesium $(\mathrm{Mg})$, and manganese $(\mathrm{Mn})$ which plants needand play a role in maintaining the balance of nutrients in the soil, because cow manure has long-term effects and is a food store for plants. Apart from using fertilizers, spinach plants also need additional growth hormones, one of the sources of growth hormone that is often used by farmers, namely atonic (Pioner, 2020).

Atonic is a growth stimulant containing the auxin hormone which acts to stimulate the growth of plant roots, increase water absorption, accelerate leaf growth and increase the number and weight of fruit (Rismawati, 2013). Atonics work biochemically directly through the roots, stems, leaves and flower buds which affect the flow of nutrients into cells and provide vital force to accelerate growth. Based on the description above, it is necessary to conduct research on "Spinach Production (Amaranthus spp.) Due to the provision of Cow and Atonic Manure in Dry Land".The objectives of this study were: to determine 
the effect of cow manure and atonic manure on spinach production in dry land.

\section{Materials and Methods}

\section{Place and time of research}

This research was conducted in October - December 2019, on the experimental field of the Faculty of Agriculture, University of Teachers' Union 1945, NTT which is located in Batuplat Village, Kota Raja District Kupang City.

\section{Materials and Tools}

The materials used in this study were local spinach seeds taken from farmers, cow manure and atonic. The tools used in this study were hoes, machetes, gembor, tape measure, scales, soil sieve, wood, ropes, knives, cameras and stationery.
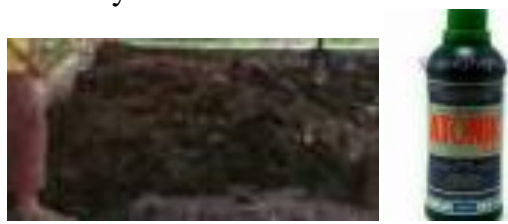

Picture 1. Cow manure and atonic

\section{Research design}

The design used was a factorial randomized block design, which consists of 2 factors, namely factor I: provision of cow manure and factor II: provision of growth stimulants (atonic).

Factor $\mathrm{I}=$ Cow manure $(\mathrm{K})$

$$
\begin{aligned}
\mathrm{K} 1 & =10 \text { tha }^{-1} \text { cow manure is equivalent to } 1 \mathrm{~kg} \\
\mathrm{~K} 2 & =\begin{array}{l}
15 \mathrm{tha}^{-1} \text { cow manure is equivalent to } 3 \mathrm{~kg} \\
\mathrm{~K} 3=\mathrm{plot}^{-1}
\end{array} \\
& \begin{array}{l}
20 \mathrm{tha}^{-1} \text { cow manure is equivalent to } 6 \mathrm{~kg} \\
\text { plot }^{-1}
\end{array}
\end{aligned}
$$

Faktor II = atonic $(\mathrm{A})$.

$\begin{array}{lll}\mathrm{A} 1 & = & \text { Atonic } 2 \mathrm{cc} \mathrm{liter} \mathrm{water} \\ \mathrm{A} 2 & = & \text { Atonic } 3 \mathrm{cc} \mathrm{liter} \mathrm{water} \\ \mathrm{A} 3 & = & \text { Atonic } 4 \mathrm{cc} \mathrm{liter} \text { water }^{-1}\end{array}$

There were 9 treatment combinations and 3 repetitions were carried out, in order to obtain 27 experimental units.

\section{Research Implementation}

Preparation of seeds

The seeds used are local variety seeds. The seeds are sown first with soil seeding media and cow manure with a ratio of 2: 1.After the seeds are 10 days old, they are transferred to the beds.

\section{Land preparation}

Before planting spinach, the land (dry land) is cleared of grass. The land is processed using a hoe with a depth of about $20-30 \mathrm{~cm}$ or around the tillage layer, then make a bed with the size of each bed is $2 \mathrm{~m} \mathrm{x} 1.5 \mathrm{~m}(\mathrm{P} \times$ $\mathrm{L})$. The distance between the beds is $30 \mathrm{~cm}$ and the distance between the repeat blocks is $50 \mathrm{~cm}$.After that it is placed, trimmed and given cow manure according to the treatment dose.

Planting

Before planting spinach, first make a planting hole, with a spacing of $20 \mathrm{~cm} \times 20 \mathrm{~cm}$. After that, put the spinach plant into the available hole. The number of spinach / hole plants is 2 plants. When the plants are 2 weeks old, thinning them is done leaving a healthy plant. Fertilization. The application of cow manure is carried out 1 week before planting with a dose according to treatment by spreading it evenly on the surface of the bed, then mixing it evenly with the ground using a hoe.After that, do watering and keep the humidity until planting.Cow manure used is fertilizer that is ripe with the characteristics of a dark color, smooth texture and does not smell strong.Atonic application was carried out twice at the age of 7 and 14 days after the concentration and time of application according to the treatment. Fertilizer is applied in the morning using a sprayer and sprayed on the leaves of the plant.

\section{Maintenance}

a) Embroidery

Replanting is done after the plants are 10 days after planting, the purpose of embroidery is to replace plants that are wilted, dead or not growing.

b) Watering.

Watering is carried out in the afternoon with the volume of water supplied to field capacity.

c) weeding Weeding is done when there are weeds growing around the plant.

d) Storage

The seasoning is done once a week, the purpose of which is to make the soil loose and to provide soil air circulation.

e) Pest and disease control

Pest and disease control is carried out when there is an attack on the plant.

Harvest

Harvesting is done when the plants are 25 days after planting. With the physical condition of the spinach plant which has characteristics, namely the lower leaves have started to turn yellow, the plant has not yet flowered and the size of the plant has been maximized both leaves, stalks and stems.

\section{Variabel Penelitian}

1. Plant height $(\mathrm{cm})$. 
Obtained by measuring the height of the plant from the base of the stem to the tip of the highest leaf at the age of 25 days after planting.

2. Number of leaves (strands)

Obtained by counting the number of leaves that have opened perfectly in the sample plant, and this is done on aged plants 25 days after planting.

3. Plant fresh weight $(\mathrm{g})$

Obtained by calculating plant fresh weight per sample plant at planting and at harvest.

4. Dry weight of stover $(\mathrm{g})$

Obtained by calculating the plant dry weight per sample plant after being oven for 24 hours at a temperature of $24{ }^{\circ} \mathrm{C}$.

\section{Data analysis}

The analytical model used in this study is a mathematical method using a randomized block design (Suhaemi, 2011).

$$
Y i j=\mu+T i+\beta j+\varepsilon i j
$$

$Y i j$ : The observed value of the ith treatment and jth repetition

$\begin{array}{ll}\mu & : \text { Common mean } \\ \beta j & : \text { Effect of repeat to }-\mathrm{j} \\ T i & : \text { Treatment effect to- } \mathrm{i} \\ i & : \text { The number of treatments }(1,2,3,4 \text { and } 5) \\ j & : \text { The number of tests }(1,2,3,4,5 \text { and } 6) \\ \varepsilon i j & : \text { Effect of treatment and repeat errors }\end{array}$

The research data obtained were analyzed using ANOVA analysis of variance to determine the effect of the treatment being tested, If there is a significant difference in this test, then continue with Duncan's continued test at the $5 \%$ level.

\section{Results and Discussion}

\section{Plant Height}

The results of analysis of variance showed that the interaction of cow manure and atonic manure had a very significant effect on the height of spinach. The average height of spinach plants due to cow manure and atonic manure can be seen in table 1 .

Table 1. Average height of spinach plants due to cow manure and atonic manure $(\mathrm{cm})$

\begin{tabular}{|c|r|r|r|r|}
\hline \multirow{2}{*}{$\begin{array}{c}\text { Factor } \\
\text { K }\end{array}$} & \multicolumn{3}{|c|}{ Factor A } & \multirow{2}{*}{ Average } \\
\cline { 2 - 4 } K1 & \multicolumn{1}{|c|}{ A1 } & \multicolumn{1}{c|}{ A2 } & \multicolumn{1}{c|}{$\mathbf{A 3}$} & \\
\hline K2 & $79.8 \mathrm{a}$ & $73 \mathrm{~b}$ & $74.3 \mathrm{c}$ & 24.122 \\
\hline $\mathbf{K 3}$ & $82.9 \mathrm{~d}$ & $79 \mathrm{e}$ & $80.5 \mathrm{f}$ & 26.311 \\
\hline Average & 19.167 & 19.783 & $91 \mathrm{i}$ & 28.811 \\
\hline
\end{tabular}

Note: The numbers followed by the same letter in the same column are not significantly different in the Duncan test $(5 \%)$.

The results of the Duncan test $(5 \%)$ showed that the highest spinach plant height was in the K3A3 treatment $\left(20\right.$ tha $^{-1}$ cow manure is equivalent to $6 \mathrm{~kg} \mathrm{plot}^{-}$ ${ }^{1}$ andatonic concentration of $4 \mathrm{cc}$ liters of water ${ }^{-1}$ ) andsignificantly different from other treatments. This is because the interaction of organic cow manure and atonic manure can increase the vegetative growth of spinach plants.Cow manure contains macro and micro nutrients in a balanced manner so that it can supply nutrients for plant growth. In addition, cow manure organic fertilizer can help improve soil structure so as to facilitate root growth and help the process of absorption of nutrients and water (Dedi, 2015).

Atonic increases root growth so as to increase the absorption of nutrients and water. $\mathrm{n}$ addition, atonic contains the hormone auxin, which plays a role in plant growth and production. Gardner (1991), explained that auxins play a role in stimulating growth by elongating cells and causing tip domination.The lowest maize plant height was in K1A1 treatment and was significantly different from other treatments. The low height of spinach in this treatment is because the plants are deficient in nutrients and inadequate exogenous hormones which result in inhibition of plant growth. Lakit (2012) explains that giving hormones in the appropriate concentration can increase plant morphogenesis, but if the growth regulators are given in excessive concentrations it will become an inhibitor for the growth of plant morphogenesis.

\section{Number of leaves}

The results of the analysis of variance showed that the interaction of cow manure and atonic manure had a very significant effect on the number of spinach leaves. The average number of spinach leaves due to cow manure and atonic manure can be seen in table 2 .

Table 2 Average number of spinach leaves due to cow manure and atonic application (strands)

\begin{tabular}{|c|r|r|r|r|}
\hline \multirow{2}{*}{$\begin{array}{c}\text { Factor } \\
\text { K }\end{array}$} & \multicolumn{3}{|c|}{ Factor A } & \multirow{2}{*}{ Average } \\
\cline { 2 - 4 } K1 & $30.0 \mathrm{a}$ & \multicolumn{1}{c|}{$\mathbf{A 2}$} & \multicolumn{1}{c|}{$\mathbf{A 3}$} & \\
\hline K2 & $44 \mathrm{~d}$ & $47 \mathrm{~b}$ & $41.5 \mathrm{c}$ & 12.000 \\
\hline $\mathbf{K 3}$ & $55 \mathrm{~g}$ & $57.5 \mathrm{~h}$ & $60 \mathrm{i}$ & 15.889 \\
\hline Average & 10.750 & 11.750 & 12.792 & 11.764 \\
\hline
\end{tabular}

Note: The numbers followed by the same letter in the same column are not significantly different in the Duncan test $(5 \%)$.

The results of the Duncan test $(5 \%)$ showed that the highest number of spinach leaves was in the K3A3 
treatment 20 tha $^{-1}$ cow manure is equivalent to $6 \mathrm{~kg}$ plot $^{-}$ ${ }^{1}$ andatonic concentration of $4 \mathrm{cc}$ liters of water ${ }^{-1}$ ) and significantly different from other treatments. This is because the interaction of organic cow manure and atonic manure is able to interact well in supplying nutrients and growth hormones which results in an increase in the number of spinach leaves.Cow manure contains macro and micro nutrients in balance, then atonic maximizes absorption. The more nutrients that are absorbed by plants, the more the plant's needs for nutrients are met. With the fulfillment of plant needs for nutrients, it can result in all plant components developing perfectly in both the vegetative and generative phases (Hariatik, 1992). The N nutrient absorbed by plants serves to encourage the growth of organs related to the photosynthesis process. The element $\mathrm{N}$ is also one of the elements needed for the development of organs in the vegetative phase, one of which is the formation of leaves (Bustami, 2012). Increased absorption of nutrients will increase the photosynthetic process which has an impact on plants and plant development.

The table above explains that the lowest number of spinach leaves was found in K1A1 treatment and was significantly different from other treatments. The low number of leaves in the treatment was due to the low absorption of nutrients.Dedi (2015), states that soil that is lacking in nutrients results in poor structure, so that it will affect the overall growth rate of plants, especially the role of $\mathrm{N}$ in the process of forming leaves that are not optimal.

\section{Plant Fresh Weight}

The results of analysis of variance showed that the interaction of cow manure and atonic manure had a very significant effect on the fresh weight of spinach. The average fresh weight of spinach plants due to cow manure and atonic manure can be seen in table 3 .

Table 3 Average fresh weight of spinach plants due to cow manure and atonic application (gr)

\begin{tabular}{|c|r|r|r|r|}
\hline \multirow{2}{*}{$\begin{array}{c}\text { Factor } \\
\text { K }\end{array}$} & \multicolumn{3}{|c|}{ Factor A } & \multirow{2}{*}{ A1 } \\
\cline { 2 - 4 } K1 & \multicolumn{1}{c|}{ A2 } & \multicolumn{1}{c|}{ A3 } & Average \\
\hline K1 & $59.5 \mathrm{a}$ & $66.5 \mathrm{~b}$ & $69.5 \mathrm{c}$ & 21.722 \\
\hline $\mathbf{K 2}$ & $73 \mathrm{~d}$ & 75.5 & $77.5 \mathrm{e}$ & 25.111 \\
\hline $\mathbf{K 3}$ & $81.8 \mathrm{f}$ & $91 \mathrm{~g}$ & $93.5 \mathrm{~h}$ & 29.589 \\
\hline Average & 17.858 & 19.417 & 20.042 & 19.106 \\
\hline
\end{tabular}

Note: The numbers followed by the same letter in the same column are not significantly different in the Duncan test $(5 \%)$.

The Duncan test results $(5 \%)$ showed that the highest fresh weight of spinach was in the K3A3 treatment (20 tha ${ }^{-1}$ cow manure is equivalent to $6 \mathrm{~kg} \mathrm{plot}^{-1}$ andatonic concentration of $4 \mathrm{cc}$ liters of water ${ }^{-1}$ ) and significantly different from other treatments. This is because the interaction of organic cow manure and atonic manure is able to interact well in supplying nutrients and growth hormones which results in an increase in the number of spinach leaves so that it has an impact on increasing photosynthetic activity (Pioner. 2020). Manure can effectively increase the cation exchange capacity is the ability of the soil to increase the interaction between ions in the soil so that it can provide the various elements needed by plants. Dede (2015), states that the nutrient potassium will enhance the movement of photosynthate from the leaves to the roots and the development of plant size. The lowest average plant fresh weight was found in treatment K1A1 and was significantly different from other treatments. This is due to the lack of nutrients and growth hormones needed by spinach during plant growth and development. Muhamad (2015), explained that if the nutrients needed by plants are available in sufficient quantities it will allow the plants to grow and produce optimally.

\section{Plant Dry Weight}

The results of analysis of variance showed that the interaction of cow manure and atonic manure had a very significant effect on spinach dry weight. The average dry weight of spinach plants due to cow manure and atonic manure can be seen in table 4 .

Table 4 Average dry weight of spinach plants due to cow manure and atonic application (gr)

\begin{tabular}{|c|r|r|r|r|}
\hline \multirow{2}{*}{ Factor K } & \multicolumn{3}{|c|}{ Factor A } & \multirow{2}{*}{ Average } \\
\cline { 2 - 4 } & \multicolumn{1}{|c|}{$\mathbf{A 1}$} & \multicolumn{1}{|c|}{$\mathbf{A 2}$} & \multicolumn{1}{|c|}{$\mathbf{A 3}$} & \\
\hline K1 & $19.0 \mathrm{a}$ & $24 \mathrm{~b}$ & $\begin{array}{r}24.5 \\
\mathrm{bc}\end{array}$ & 7.500 \\
\hline K2 & $25 \mathrm{c}$ & $26 \mathrm{~d}$ & $28 \mathrm{e}$ & 8.778 \\
\hline K3 & $29.5 \mathrm{f}$ & $31 \mathrm{~g}$ & $34 \mathrm{~h}$ & 10.500 \\
\hline Average & 6.125 & 6.750 & 7.208 & 6.694 \\
\hline
\end{tabular}

Note: The numbers followed by the same letter in the same column are not significantly different in the Duncan test $(5 \%)$.

The Duncan test results (5\%) showed that the highest dry weight of spinach was in the K3A3 treatment (20 tha ${ }^{-1}$ cow manure is equivalent to $6 \mathrm{~kg}$ plot $^{-1}$ andatonic concentration of $4 \mathrm{cc}$ liters of water ${ }^{-1}$ )and significantly different from other treatments.This is because the interaction of organic cow manure and atonic manure is able to interact well in supplying nutrients and growth hormones.Cow manure contains macro and micro nutrients in a complete and balanced manner so as to increase photosynthetic activity. Furthermore, atonic will maximize nutrient and water uptake. Uptake has a strong correlation with crop stover weight. The higher the plant nutrient uptake, the higher the plant stover weight (Hartatik, 1992). 
The addition of manure can improve the physical and biological properties of the soil so that it allows plants to absorb nutrients optimally for their growth and development.Gardner et al. (1991), fertilizing in the deficient zone will increase the dry weight of the plant, whereas fertilization in the excessive zone will result in an increase in the content of certain nutrients in plant tissue. If this happens, fertilization efficiency will not be achieved, thereby increasing absorption. The lowest dry weight of spinach stover was on K1A1 treatment and significantly different from other treatments. This is thought to be due to insufficient nutrients in the soil, thus inhibiting the process of plant growth and development. Arifin et al. (2010), states that nutrient deficiency can lead to inhibition of cell growth which causes plant weight to decrease.

\section{Conclusion}

Based on the results and discussion, several conclusions can be drawn, namely: Application of cow and atonic manure to spinach on dry land has a very significant effect on plant height, number of leaves, fresh weight and dry weight.

\section{Acknowledgements}

Praise be to God Almighty for His Power and Mercy so that this article can be completed properly.During this activity, the implementation team received moral and material assistance from various parties for 6 months. Therefore, on this occasion we would like to thank: Chancellor and Dean of the Faculty of Agriculture, University of the 1945 NTT Teachers Association who has helped both morally and materially in the implementation of this activity.

\section{References}

Andrie KL, Marisi Napitupulu \& Noor Jannah (2015). Respon Tanaman Mentimun (Cucumis sativus L.) Terhadap Jenis Poc Dan Konsentrasi Yang Berbeda. $\quad$ http://ejurnal.untagsmd.ac.id/index.php/AG/article/view/1097.

Anton Sulistio, Hery Sutejo \& Marisi Napitupulu (2018). Effect of Petroganic Fertilizer and Growmore Fertilizer on the Growth and Production of Hot Chilli (Capsicum frutescens L.), Dewata 43 F1 Variety. http://scholar.google.co.id/citations?user=cjbeCB sAAAAJ\&hl=id.

Arifin Syamsudin, Sri Nuryani H Utami \& Bostang Radjagukguk (2010). The Effect of Interaction of Nitrogen and Phosphorus Nutrients on Growth of
Corn (Zea Mays L) on Regosol and Latosol Soils. Biology News 10(3) - December 2010. https://media.neliti.com/media/publications/6851 8-ID-none.pdf

Dede Haryadi, HusnaYetti \& Sri Yoseva (2015). Effect of some types of fertilizer on the growth and production of kailan (brassica alboglabra 1.) Effect of some types of fertilizer on the growth and production kalian.https://media.neliti.com/media/publications /199801-pengaruh-pemberian-beberapa-jenispupuk.pdf

Ely Evanita, Eko Widaryanto \& Y.B Suwasono Heddy (2014). The Influence of Cattle Dropping Fertilizer on Growth and Yield of The Eggplant (Solanum Melongena L) In Intercropping Pattern with Napier Grass (Penisetum purpureum) OF THE FIRST CROP https://media.neliti.com/media/publications/1284 40-ID-pengaruh-pupuk-kandang-sapi-padapertumb.pdf

Farisa Magdalena, Sudiarso \& Titin Sumarni (2013). Use of manure and green manure by Crotalaria juncea L. To reduce the use of inorganicfertilizers on maize (Zea mays L.). Jurnal Produksi Tanaman, 1 (2). ISSN: 23383976.https://media.neliti.com/media/publications/ 125970-ID-penggunaan-pupuk-kandang-danpupuk-hijau.pdf

Gardner FP, Pearce RB \& Mitchell RL (1991). Physiology of Crop Plants. Jakarta. Indonesia University Press.

Hartatik (1992). Comparison of NPK Elements in Cow Manure and Chicken Manure Organic Fertilizer with Local Micro Organism Breeding (MOL). https://media.neliti.com/media/publications/1732 96-ID-perbandingan-unsur-npk-pada-pupukorgani.pdf

Hendra, Sakka Samudin \& Muhammad Anshar (2016). Analysis of Plant Growth of Lembah Palu ShallotVariety (Allium cepa L. Aggregatum Group) Grown under the Addition of Atonic and Liquid Organic Fertilizer. http://jurnal.untad.ac.id/jurnal/index.php/AGROL AND/article/download/8115/643

Imelda Dada Gole1, I Made Sukerta \& Bagus Putu Udiyana (2019). Pengaruh Dosis Pupuk Kandang Sapi Terhadap Pertumbuhan Tanaman Sawi (Brassica juncea L.). 
http://journal.unigha.ac.id/index.php/JAR/article/ view/191

Karnilawati, Abdul Gani \& Sayuti. (2018). Effect of Types of Plant Media and Concentration of Atonik ZPT on Growth of Papaya Plant (Carica papaya L). http://journal.unigha.ac.id/index.php/JAR/article/ download/191/191

Komang Suta Darmawan, I Gusti Bagus Udayana, A A Ngurah Mayun Wirajaya \& Made Sri Yuliartini (2020). Pengaruh Konsentrasi Atonik dan Dosis Pupuk Kandang Sapi Terhadap Pertumbuhan Bibit Kelapa Sawit (Elaeis guineensis Jacq) Sistem Prenursery.

http://ejournal.warmadewa.ac.id/index.php/gemaagroe-ISSN 2614-6045. 25 (01): 17-22

Lakitan, Benyamin. (2012). Basics of Plant Physiology. Jakarta: PT. Radja. GrafindoPersada

Muhammad Habibullah \& Idwar, Murniati (2015). Effect of N, P, K and Liquid Organic Fertilizer (Poc) on Growth, Yield and Efficiency of Upland Rice (Oryza sativa L.) Production in Ultisol Soil Medium. JOM Faperta Vol. 2 No. 2 Oktober 2015. https://media.neliti.com/media/publications/2024 89-none.pdf

Musdalifah Musdalifah \& Marisi Napitupulu (2020). Pengaruh Pupuk Kandang Sapi Dan Pupuk Gandasil B Terhadap Pertumbuhan Dan Hasil Tanaman Buncis (Phaseolus vulgaris L) varietas lebat-3.http://ejurnal.untagmd.ac.id/index.php/AG/article/view/4618

Pande Gede Gunamanta, Ketut Turaini Indra Winten \& Anak Agung Gede Putra (2019). Aplikasi zat pengatur tumbuh dengan pupuk kandang dapat meningkatkan produksi buah mentimun (Cucumis sativus L.). http://journal.unmasmataram.ac.id/index.php/GA RA

Pioner (2020). Factors Affecting Plant Growth. https://www.pioneer.com/web/site/indonesia/Fakt or-Faktor-yang-Mempengaruhi-Pertumbuhandan-Perkembangan-Tanaman

Rice Bustami (2012). Nutrient Uptake and Efficiency of Phosphate Fertilization and Growth of Local Varieties of Rice. http://www.jurnal.unsyiah.ac.id/MSDL/article/do wnload/2184/2141
Rismawati \& Syakhril (2013). Responses of the Origin of Red Betel Cuttings (Piper crocatum Ruiz and Pav.) To the Concentration of Rootone Fhttps://media.neliti.com/media/publications/300 87-ID-respons-asal-bahan-stek-sirih-merah-pipercrocatum-ruiz-and-pav-terhadap-konsent.pdf

Suwarni Tri Rahayu, Ali Asgar, Iteu M Hidayat, Kusmana \& Diny Djuariah (2013). Evaluation of the Quality of Several Genotypes of Spinach (AmaranthusSp) in Planting in West Java. Biologi News 12(2) Agustus 2013. https://media.neliti.com/media/publications/6788 3-ID-none.pdf 